\section{Quantitation of myeloperoxidase from human granulocytes as an inflammation marker by enzyme-linked immunosorbent assay}

\author{
S. Neumann ${ }^{1}$, G. Gunzer ${ }^{1}$, H. Lang ${ }^{1}$, Marianne Jochum ${ }^{2}$, \\ and H. Fritz ${ }^{2}$ \\ ${ }^{1}$ Biochemische Forschung E. Merck, Frankfurter Straße 250, \\ D-6100 Darmstadt 1, Federal Republic of Germany \\ 2 Abteilung für Klinische Chemie und Klinische Biochemie, \\ Chirurgische Klinik der Universität München, \\ Nußbaumstraße 20, D-8000 München 2, \\ Federal Republic of Germany
}

\section{Quantifizierung von Myeloperoxidase aus humanen Granulocyten als Entzündungsparameter mittels Enzymimmunoassay vom Sandwichtyp}

Myeloperoxidase (donor: $\mathrm{H}_{2} \mathrm{O}_{2}$ oxidoreductase, $\mathrm{EC}$ 1.11.1.7) is a cationic heme enzyme of mol wt of approximately 140,000 which is found as a main constituent of the azurophilic granules of polymorphonuclear leukocytes (PMN) and in monocytes [1]. Myeloperoxidase (MPO) plays an important role in killing bacteria using halide ions as a cofactor [2]. As a consequence of phagocytosis MPO is discharged into phagolysosomes. Leakage during phagocytosis or secretion on stimulation by various inflammatory mediators causes the appearance of extracellular MPO activity. MPO activity outside of the cells may either stimulate inflammatory processes by oxidation of physiological substrates like IgG, C3b, $\alpha_{1}$-proteinase inhibitor as well as latent collagenase and by killing cells or may alternatively modulate inflammatory activity by inactivation of chemotactic peptides, lysosomal enzymes as well as Fc- and C3b-receptors on phagocytes [3]. Quantitative determination of MPO in serum or plasma has been accomplished by radioimmunoassay [4] and in cell extracts or tissue extracts by enzyme assays. Here we describe a sandwich-type enzyme-linked immunosorbent assay for quantitation of MPO concentration in plasma, bronchoalveolar lavage fluid or extracts from granulocytes.

\section{Materials and methods}

MPO was purified from normal human granulocytes by a procedure involving acid extraction of granules, copper chelate chromatography, cation exchange chromatography on SPSephadex ${ }^{R T M}$ C-50 and size exclusion chromatography on Fractogel ${ }^{\text {RTM }}$ TSK HW-55. The final enzyme preparation was shown to be free of other granular proteins by SDS-polyacrylamide gel electrophoresis and immunoelectrophoresis against various polyvalent or monospecific antisera against granular components. - Antigen-specific antisera to MPO were raised in sheep and rabbits. The IgG fractions were isolated by ammonium sulfate precipitation and ion-exchange chromatography on DEAE cellulose. The specific IgG fraction from rabbits was isolated by adding immunoadsorption on MPO-agarose, and then coupled to calf intestinal alkaline phosphatase with glutardialdehyde as described previously [5].

For the enzyme immunoassay a procedure as reported previously for the complex of PMN elastase with $\alpha_{1}$-proteinase inhibitor was followed analogously [6]. Briefly, polystyrene tubes $(10.5 \mathrm{~mm} \times 40 \mathrm{~mm})$ were coated by incubation with $0.5 \mathrm{ml}$ containing $50 \mu \mathrm{g}$ sheep IgG to $\mathrm{MPO} / \mathrm{ml}$ in phosphate buffered saline $\mathrm{pH} 7.5$ (PBS) at room temperature $\left(20\right.$ to $\left.22^{\circ} \mathrm{C}\right)$ overnight and washed with $0.05 \%(\mathrm{w} / \mathrm{v})$ polyoxyethylene (20)-sorbitan monolaurate several times before use. For the assay $0.5 \mathrm{ml}$ sample or calibrator was incubated in the coated tubes for $1 \mathrm{~h}$ at 20 to $22^{\circ} \mathrm{C}$. The tubes were washed three times, and $0.5 \mathrm{ml}$ enzyme labelled antibodies to MPO in saline Tris $/ \mathrm{HCl}$ buffer $\mathrm{pH} 8.0$ was added. After incubation for $2 \mathrm{~h}$ at 20 to $22^{\circ} \mathrm{C}$ and washing of the tubes $0.5 \mathrm{ml}$ substrate solution, i.e. $10 \mathrm{mmol} / \mathrm{l}$ 4-nitrophenyl phosphate in $1 \mathrm{~mol} / 1$ diethanolamine $/ \mathrm{HCl}$ buffer $\mathrm{pH} 9.8$ with $0.5 \mathrm{mmol} \mathrm{MgCl}_{2} / 1$, was delivered to each tube and incubated for $1 \mathrm{~h}$ at 20 to $22^{\circ} \mathrm{C} .0 .5 \mathrm{ml} 2 \mathrm{~mol} / 1 \mathrm{NaOH}$ was added with vortexing. Absorbance was read at $405 \mathrm{~nm}$. $\mathrm{A}_{405}$ was plotted against MPO concentration on a linear scale. As a routine citrated plasma was used in a final dilution of one part plasma plus 20 or 50 parts of PBS containing $1 \mathrm{mg}$ bovine serum albumin $/ \mathrm{ml}$ and $20 \mathrm{mmol}$ EDTA/l. Calibrators were used in the same diluent plus $2 \%(\mathrm{v} / \mathrm{v})$ citrated normal sheep plasma.

\section{Results and discussion}

A linear calibration curve was obtained for the range of 0 to $20 \mu \mathrm{g} \mathrm{MPO} / 1$. Unknowns were determined by reference to the calibration curve as calculated by linear regression analysis. Detection limit, i.e. mean absorbance of the blank plus $3 \times$ standard deviation, was about $0.25 \mu \mathrm{g} / \mathrm{l}$. Sensitivity corresponded to $\Delta \mathrm{A}=0.004$ in the calibration curve and approached $0.1 \mu \mathrm{g} \mathrm{MPO} / 1$. Within-run imprecision (coefficient of variation for 15 parallel determinations) was in the range of 8.4 to $6.8 \%$ with plasma samples in the range of 32 to $143 \mu \mathrm{g}$ $\mathrm{MPO} / \mathrm{l}$, respectively. Between-run imprecision (CV for a series of 9 independent tests) was from 5.2 to $12.2 \%$ for 3 different commercially obtainable control plasma specimen. The assay was shown to be specific for myeloperoxidase as lactoferrin as well as other granular proteins when added to the sample did not interfere. However, plasma concentrations higher than 5\% (v/v) impaired recovery, possibly by matrix effect(s). As the assay showed high sensitivity and reasonable precision with control plasma specimen we went on to measure myeloperoxidase levels in normal and pathological samples. In a group of 156 apparently healthy persons the MPO concentration in citrated plasma was $36 \pm 11.5 \mu \mathrm{g} \mathrm{MPO} / 1$ (mean $\pm \mathrm{SD}$ ). In another group of 25 normal persons similarly a range of 20 to $60 \mu \mathrm{g} / \mathrm{l}$ was found.

Patients suffering from multiple trauma were studied longitudinally with $6 \mathrm{~h}$ intervals, measuring in citrated plasma MPO as well as the complex of PMN elastase with $\alpha_{1}$-proteinase inhibitor which was previously shown to reflect the severity of the disease as well as complication by infections [7]. Plasma levels of MPO showed a perfect correlation with the PMN elastase complex levels with regard to rise and fall, they were, however, lower in terms of concentration. Quite differently, in patients with adult respiratory distress syndrome (ARDS) in the analyses of bronchoalveolar lavage fluid high levels of MPO were observed which were equal to or in severe cases even higher than the concentration of the PMN elastase complex. It is argued that the availability of active $\alpha_{1}$-proteinase inhibitor for inactivation of PMN elastase may be limited here locally, and high levels of MPO may both signal the acuity of the disease process and indicate the oxidative potential at the site of inflammation.

\section{References}

1. Schultz J (1980) In: Sbarra AJ, Straus RR (eds) The reticuloendothelial system, vol 2. Plenum Press, New York, pp $231-254$

2. Klebanoff SJ (1975) Sem Hematol 12:117-142

3. Clark RA (1983) In: Weismann G (ed) Advances in inflammation research, vol 5. Raven Press, New York, pp 107-146

4. Olofsson T, Olsson I, Venge P, Elgefors B (1977) Scand J Haematol 18:73-80

5. Neumann S, Jochum M (1984) In: Bergmeyer HU (ed) Methods of enzymatic analysis, 3rd edn, vol V. Verlag Chemie, Weinheim, pp 184-195

6. Neumann S, Gunzer G, Hennrich N, Lang H (1984) J Clin Chem Clin Biochem 22:693-697

7. Dittmer H, Jochum M, Schmit-Neuerburg KP (1985) Chirurg 56:723-727 